\title{
Morpho-Syntactic, Lexical and Semantic Curiosities in the Naming Practice in Ghomala'
}

\author{
WEGA SIMEU, PhD \\ The University of Bamenda \\ Higher Teachers' Training College
}

\begin{abstract}
This article analyses the naming practice in Ghòmálá', a Bantu Grassfield language spoken in the West Region of Cameroun. Our interest in this paper can be stated in the following queries: what is behind the sounds that make up the morphemes and the words used in Ghòmálá' language as Names? What are the morphological structure and the semantic implications of names in this area? Our objectives in this paper are manifold: first, we want to identify the various morphosyntactic structures of Ghòmálá' names. Secondly, it is aimed to discuss their semantic implications. Thirdly we want to sensitize the native speakers to enhance the value of their culture and identity through their family names. And finally to derogate the mental colonization and the excessive attribution of borrowed names to Cameroonian children, which in fact is taking them away from their culture, language and identity. The data used in this research were collected mainly from the central and Southern Ghóèmaàlaà' dialects. About one thousand (1000) names were collected and transcribed with IPA symbols. The analysis was carried out following the American School of structuralism (Bloomfield, 1933; Harris 1957) andAnthropo linguistics (Duranti 2003; Lévi-Strauss 1953-1973). The findings show that Ghòmálá' names are mostly made up of a concatenation of Phrases and Clauses, namely NPs, VPs, and Non verbal Clauses. Ghòmálá’ names are monosyllabic, disyllabic, trisyllabic and quadrisyllabic. Many linguistic processes such as derivation, verb flexion are also present.
\end{abstract}

Keywords: Culture, Ghòmálá', Identity, Language, Lexicon, Morpheme, Naming, Semantics

\section{O.Introduction}

Scientific and technological development, as well as contact with the western civilization is making the Ghòmálá' speakers lose their cultural values and identities. Culture and identity are transmitted and expressed through language. As a matter of fact, language portrays the daily life and thought of the people who speak it. Naming can be defined as the fact of choosing or giving a name to a baby. Naming contributes to the shaping of people's identities, as it is from name and mother tongue that a child receives his first identity. As a matter of fact, naming and mother tongue are paramount levers of the identity and culture, and a plinth which underdeveloped countries that are struggling to emerge should lean on. This paper therefore studies the morphological structure of names in the area by questioning the lexical structure and the semantic contents of the names that the Ghòmálá' natives are given. Our worry is to know to which extent cultural practices can promote identity and endogenous development. We then, got interested by naming practice in Cameroon and we chose our native area «the Ghòmálá' linguistic area ». Our main query in this article is the following: to which extent can naming contribute to cultural nationalism in Cameroon? What is behind the sounds that make up the morphemes and the words used in Ghòmálá' language as Names? What are the morpho-syntactic structure and the semantic implications of names? What are the criteria for naming one's child? The main hypothesis is that Naming and mother tongue are paramount levers of identity and cultural nationalism. This paper seeks to entrench Cameroonian in their culture and identity; to sensitize Cameroonian on the richness of home names; to sensitize the native speakers to enhance the value of their culture and identity through their family names; to contribute to cultural nationalism through naming. Moreover, the aim of the article is to derogate the mental colonization and the excessive attribution of borrowed names to Cameroonian children, which in fact is taking them away from their culture, language and identity. There is very little literature on naming practice in Cameroonian languages. Ekanjume-Ilongo (2014) only focused on a cultural and identity aspect played by naming within a multicultural and globalization context. 
Nzali (1987) attempted an anthropological study of names in the Bandenkop dialect of Ghòmálá'.Very few authors have paid attention to the morphosyntactic structure of African names and its semantic implications.

\section{1- The Ghòmálá’ linguistic area and classification}

Ghóèmaàlaà' is a Grassfield Bantu language, spoken in five divisions of the Western region in Cameroon namely: Mifi, Koung-Khi, Haut-Plateaux, Menoua and the Bamboutos division. According to Grimes (2010), native speakers of Ghòmálá' language are estimated at about 260,000 on a total area of 1,170 km2. The Ghòmálá' linguistic area is made up of 16 Paramount villages (Kingdoms): Bafoussam, Baleng, Bapi, Bandjoun, Baham, Bayangam, Bahouan, Batié, Bandenkop, Bapa,Bangam,Bamougoum,Bamendjou, Bameka, BansoaandBafounda.

Ghóèmaàlaà'is assigned the code 960 (Dieuand Renaud, 1983) and includes four varieties of dialects more or less homogeneous: Southern Ghòmálá' (Batié, Bandenkop, Bapa,Bangam), Central Ghòmálá' (Bandjoun,Baham, Bayangam, Bahouan), Northern Ghóèmaàlaà'(Bafoussam, Baleng, Badeng, Bapi) and westernGhóèmaàlaà'also termed asฤgémba(Bamendjou, Bameka, Bansoa,Bafounda). The Ghóèmaàlaà' language is limited by the following languages: Mungaka, Shupamem, Fé'efé', Yemba, Ngomba andNda'nda'. Grimes (2010) presents the following classification for Ghomala': Niger-kordofian, Niger-congo, Benoue-Congo, Bantoïd, Bantu, Grassfield Bantu, East grassfield, central Bamileke. This classification is based on the genetic nature of the language, its morphological behavior and its internal structure.

\section{2- Methodology of data collectionand Theoretical framework}

This section presents the data collection methodology and theoretical plinth which this paper leans on. It goes without saying that the importance of any scientific work is also determined by its theoretical orientation. The data were collected mainly from the central (Bandjoun) and Southern (Batié) Ghòmálá'. About one thousand (1000) names were collected and transcribed with IPA symbols. The collected data were perused and codified manually. We then classified them (the data) according to their shape, size and theme. The study is leaning on two theories: structuralism (De Saussure 1916) in its American trend known as Behaviorism (Bloomfield 1933; Harris 1957) and Anthropo linguistics (Duranti 2003; Lévi-Strauss 1953-1973). The operatory principle of the latter consists of collecting and describing linguistic data according to the norms of the structural linguistics and anthropology. According to Lévi-Strauss (1973 :388), Anthropology vise à une connaissance globale de l'homme, embrassant son sujet dans toute son extension historique et géographique ; aspirant à une connaissance applicable à l'ensemble du développement humain. Structuralism on the hand, as postulated by Saussure (1916) is based on an essential principle: the consideration of language as a structure, that is, a well-organized system in which the parts are arranged and connected together. The methodology of collecting and analyzing the data described aboveis purposely adapted firstly to Anthropo linguistics and secondly to Behaviorism (also termed as Distributionnalism) which is an American trend of Structuralism.

\section{3- Morphological structure of Ghòmálá’ names}

Morphologically Ghòmá lá’ names are monosyllabic, disyllabic, disyllabic and quadrisyllabic.

3.1- Monosyllabic names

This structure is very rare in the language and bears no meaning. We could only have one name out the 1000 that make up our data. Table 1 displays an example of such name. Let us consider the example in table 1:

Table 1

\begin{tabular}{|l|l|l|l|}
\hline Morphological Form & Phonetic Form & French writing & Gloses \\
\hline Imbà $\mid$ & {$[\mathrm{mbà}]$} & Mba & $?$ \\
\hline
\end{tabular}

\subsection{Disyllabic names}

The majority of Ghòmálá' names are disyllabic; we could identify 778 names out the 1000 names that were collected. These disyllabic names encompass noun phrases, verb phrases and reduplications. Table 2 displays instances of disyllabic names 
Table 2

\begin{tabular}{|c|c|c|c|}
\hline Morphological Form & Phonetic Form & French writing & Gloses \\
\hline $\begin{array}{l}\mid \grave{m}-\text { pǔn-sí } \mid \\
\text { Cl1-poverty-God }\end{array}$ & [m̀bǔnsí ] & Mbungsi & $\begin{array}{l}\text { The poorman of } \\
\text { God }\end{array}$ \\
\hline $\begin{array}{l}\mid \text { sí-mø̀| } \\
\text { God-person }\end{array}$ & [símø̀] & Simo & $\begin{array}{l}\text { The God of } \\
\text { somebody }\end{array}$ \\
\hline $\begin{array}{l}\mid \text { mø̀-pín| } \\
\text { Person- accept }\end{array}$ & [mø̀pín] & Moping & $\begin{array}{ll}\begin{array}{l}\text { Let } \\
\text { agree! }\end{array} & \text { somebody } \\
\end{array}$ \\
\hline $\begin{array}{l}|l i ̀-l i ̀| \\
\text { Search-search }\end{array}$ & [lìlì] & Lili & $\begin{array}{l}\text { Continue } \\
\text { searching }\end{array}$ \\
\hline $\begin{array}{l}\mid \text { pòn-m̀-pín| } \\
\text { Well -and-.accept }\end{array}$ & [pònm̀bín] & Ponbing & $\begin{array}{l}\mathrm{Be} \text { well and } \\
\text { acknowledge it }\end{array}$ \\
\hline
\end{tabular}

From this table we observe that disyllabic names are made up of associative constructions and reduplications 3.3 Trisyllabic names and more

We could identify 222 names out the 1000 names that were collected, giving a percentage of $22,2 \%$. Table 3 displays instances of trisyllabic names:

Table 3

\begin{tabular}{|c|c|c|c|}
\hline Morphological Form & Phonetic Form & French writing & Gloses \\
\hline $\begin{array}{l}\mid \text { tì-pòn-mø̀ } \\
\text { Without-good-person }\end{array}$ & [tìpònmø̀] & Tipongmo & The bad person \\
\hline 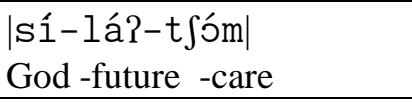 & [síláPtfóm] & Silatchom & $\begin{array}{l}\text { God will care one } \\
\text { day }\end{array}$ \\
\hline $\begin{array}{l}\text { |nwə̀-pəpóy| } \\
\text { Issue good }\end{array}$ & [nwə̀pəpón] & Noupepong & The good problem \\
\hline $\begin{array}{l}\text { |tì-mbòn-sú| } \\
\text { Without-good-friend }\end{array}$ & [tìbònsú ] & Tibongsou & $\begin{array}{l}\text { without a good } \\
\text { friend }\end{array}$ \\
\hline 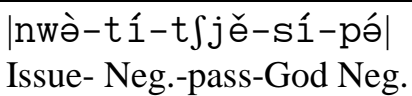 & 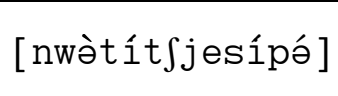 & Noutchetchiesi & $\begin{array}{l}\text { Nothing can } \\
\text { overwhem God }\end{array}$ \\
\hline
\end{tabular}

From this table, we observe that trisyllabic names are verb phrases, clauses and noun phrases. The morphological analysis of Ghòmálá' names has permitted us know the size and shape of the names, what about the syntax or the horizontal ordering?

\section{4- The morphosyntactic structure of Ghòmálá' names}

Ghòmálá' names are mostly made up of a concatenation of Phrases and Clauses, namely NPs, VPs, and verbal Clauses. Many linguistic processes such as derivation, verb flexion are also present. Noun phrase names include Associative NPs (Genitival NPs), Negative NPs.

\subsection{Associative NPs names}

In associative NPs or genitive NPs nameswe have two nouns that are linked by a morpheme which could be segmentally or non-segmentally realised (Tamanji\&Ndamsah, 2004). In Ghòmálá’, the constituents are either linked by a floating low or high tone. In table 4, $A M$ stands for Associative Marker. Let us consider the examples: 
Table 4

\begin{tabular}{|c|c|c|c|}
\hline Morphological Form & Phonetic Form & French writing & Glosses \\
\hline $\begin{array}{l}\text { |sí-`-mø̀| } \\
\text { God -AM -person }\end{array}$ & [sîmø̀ ] & Simo & Somebody's God \\
\hline $\begin{array}{l}\mid \text { j̀gǿp-`-sí| } \\
\text { Fowl-AM- God }\end{array}$ & [ygôpsí] & Ngopsi & God's fowl \\
\hline $\begin{array}{l}\mid \grave{y ̀-y a ̀ n-`-n w ə \mid ~} \\
\text { Cl1- owner AM problem }\end{array}$ & [ ’̀yànnwə] & Ngannou & $\begin{array}{l}\text { Man with many } \\
\text { problems }\end{array}$ \\
\hline 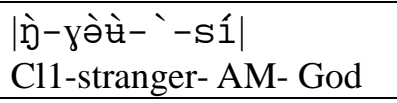 & [ગ̀yə̀tેsí ] & Ngueussi & Grod's stranger \\
\hline $\begin{array}{l}\mid \text { mø̀-`-mø̀| } \\
\text { person -AM -somebody }\end{array}$ & [mø̀mø̀ ] & Momo & Somebody's person \\
\hline $\begin{array}{l}\mid \text { |̀-yòm-`-sí| } \\
\text { Cl5-speech -AM- God }\end{array}$ & [ìyǒmsí] & Ghomsi & God 's speech \\
\hline $\begin{array}{l}\text { |ngù?-`-nwò| } \\
\text { year -AM -problem }\end{array}$ & [ ngù?nwə̀ ] & Ngounou & The year of problems \\
\hline
\end{tabular}

The associative NPs or genitive NPs in Ghòmálá' names are constructed mainly through prefixation of either the class one noun class marker $|\grave{\mathrm{N}}-|$ or the word $|\mathrm{sí}-|$. The latter can also appear in some names as suffix. From left to right, the structure of the associative NPs in Ghòmálá' name sis made up of the head noun (HN), the associative marker (AM) and the associated noun (AN). This is structured as follows: HN+AM+AN.

4.2 Negative NPs names

The negative NPs names in Ghòmálá' are constructed through the prefixation of the negation marker $|t i ̀-|$ to the noun. This is structured as follows:

Negative NPs names $=\mathrm{Neg}+\mathrm{AN}$. Let us consider the examples in the table below:

Table 5

\begin{tabular}{|c|c|c|c|}
\hline Morphological Form & Phonetic Form & French writing & Glosses \\
\hline $\begin{array}{l}\mid \text { tì-mø̀| } \\
\text { Without-person }\end{array}$ & [tìmø̀] & Timo & He who has nobody \\
\hline $\begin{array}{l}\mid \text { tì-pòn-mø̀| } \\
\text { Without- good- person }\end{array}$ & [ tìpònmø̀ ] & Tipongmo & The bad person \\
\hline $\begin{array}{l}\mid \text { tì-zǿ| } \\
\text { Without-name }\end{array}$ & [tìzǿ] & Tizeu & $\begin{array}{l}\text { He who has no name } \\
\text { (unfamous somebody) }\end{array}$ \\
\hline $\begin{array}{l}\mid \text { tì-mø̀-mbè } \mid \\
\text { Without-person -home }\end{array}$ & [ tìmø̀mbè ] & Timombé & Nobody was there \\
\hline
\end{tabular}

From this table, we observe that negative NPs names are constructed mainly through prefixation of negation marker. In a name like $|\mathrm{t} \grave{i}-\mathrm{m} \varnothing|$, we have $|\mathrm{t} \grave{i}-|$ "without" plus |-møे| "somebody, person". 4.3 Specificative or Qualificative NPs names

The Qualificative NPs names in Ghòmálá’ are made up of qualificative adjectives and determiners. Let us consider the examples:

Table 6

\begin{tabular}{|l|l|l|l|}
\hline Morphological Form & Phonetic Form & French writing & Glosses \\
\hline $\begin{array}{l}\text { İ̀-pòn-sú| } \\
\text { Cl1-Good- friend }\end{array}$ & [mbònsú ] & Mbonsou & Good friend \\
\hline $\begin{array}{l}\text { |nwə̀-pə̀pón| } \\
\text { issue good }\end{array}$ & [nwòpòpón] & Noupepong & Good issue \\
\hline
\end{tabular}




\begin{tabular}{|l|l|l|l|}
\hline $\begin{array}{l}\text { Inwè-nóné| } \\
\text { issue - true }\end{array}$ & [nwènə́né ] & Nounéné & The truth \\
\hline
\end{tabular}

In this table, the nouns: |sú| "friend" ,|nwò| "problem", are specified or qualified by the adjectives: |pòn| "good", |pón| "good", |nóné| "true"

4.4 Quantificative NPs names

The quantificative NPs names in Ghòmálá' are made up of quantifiers and numerals. Let us consider the examples:

Table 7

\begin{tabular}{|c|c|c|c|}
\hline Morphological Form & Phonetic Form & French writing & Glosses \\
\hline $\begin{array}{l}\text { |mélà-nwò } \mid \\
\text { Many probem }\end{array}$ & [mع́lànwə̀] & Malanou & Many problems \\
\hline 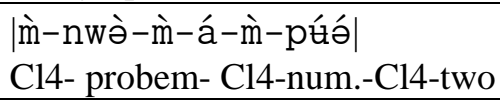 & [m̀nwə̀mǎmbúó ] & Noumabeu & Two problems \\
\hline $\begin{array}{l}\mid \text { ndà?-sí } \\
\text { only- God }\end{array}$ & [ndà1sí] & Dassi & Only God \\
\hline
\end{tabular}

In this table, the nouns: |sí| "God", |nwò|"problem", are quantified or numbered by quantifiers: |mélà|"many", and |ndà?|"only", and by the numeral: |púá| "two",|

4.5 The verb phrase (VP) names

Verb phrase names in Ghòmálá' is a concatenation of morphological elements in which the verb is the head. We could identify between declarative, imperative, interrogative, and negative verb phrase names.

4.5.1 Declarative verb phrase names Declarative verb phrase names are made of up a Noun (or pronoun) + Tense Marker(TM) +verb. Let us consider the examples:

Table 8

\begin{tabular}{|c|c|c|c|}
\hline Morphological Form & Phonetic Form & French writing & Glosses \\
\hline $\begin{array}{l}\mid \text { sí-'- pín| } \\
\text { God -TM - agree }\end{array}$ & [sǐpín] & Siping & God has agreed \\
\hline $\begin{array}{l}\mid \text { |ggà-’ yé } \mid \\
\text { I -TM- see }\end{array}$ & [ngǎyé] & Ngayé & I have seen it \\
\hline $\begin{array}{ll}\mid \text { |ggà- } & \text {-pín| } \\
\text { Iname- TM - agree } & \end{array}$ & [ngǎpín] & Ngaping(si) & Thank you (God) \\
\hline $\begin{array}{l}\text { |sí-lá?-tjóm } \mid \\
\text { God-TM - care }\end{array}$ & [síláPtfóm ] & Silatchom & $\begin{array}{l}\text { God will care one } \\
\text { day }\end{array}$ \\
\hline $\begin{array}{l}\mid \text { nwò-' - }{ }^{\prime}-j^{\prime} \text { óm } \mid \\
\text { Issue- TM- AM- many }\end{array}$ & [nwə̌ǹjóm ] & Nunjom & $\begin{array}{l}\text { Problems are } \\
\text { many }\end{array}$ \\
\hline
\end{tabular}

From the table above, we observe that, the name [ ggǎyé] is morphologically made up of: |Đgà-|"I", which is a pronoun that functions as noun, $\left.\right|^{\prime} \mid$ the high tone here is the Tense Marker, |pín|"accept" is the verb, yielding thus a declarative verb phrase structure.

4.5.2 Interrogative Verb Phrase Names

Interrogative Verb Phrase Names are made of up an interrogative pronoun + Tense Marker(TM) +verb. Let us consider the examples:

Table 9

\begin{tabular}{|c|c|c|c|}
\hline Morphological Form & Phonetic Form & French writing & Glosses \\
\hline 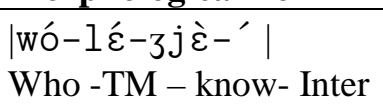 & [wólézjěc] & Woleje & Whoever knows? \\
\hline
\end{tabular}




\begin{tabular}{|l|l|l|l|}
\hline $\begin{array}{l}\text { |kə̀-’ mbí-wó| } \\
\text { What- TM -to -who }\end{array}$ & [kǒmbíwó $]$ & Kabiwa & Who has what? \\
\hline
\end{tabular}

From the table above, we observe that, the name [wólézj ž] is morphologically made up of: |wó-|"who", which is an interrogative pronoun that functions as subject, $|1 \mathcal{\varepsilon}|$ is the Tense Marker, $|3 j \dot{\varepsilon}| " k n o w "$ is the verb, $\left.\right|^{\prime} \mid$ the high tone here is the interrogative intonation, yielding thus an interrogative verb phrase structure.

4.5.3 Negative Verb Phrase Names

Negative Verb Phrase Names are made of up NOUN +TM+ NEG+VERB. Let us consider the examples:

Table 10

\begin{tabular}{|c|c|c|c|}
\hline Morphological Form & Phonetic Form & French writing & Glosses \\
\hline $\begin{array}{l}\mid \text { sì-'-kà?-pín| } \\
\text { God-TM- Neg.-agree }\end{array}$ & [sǐkàPpín] & Sikaping & $\begin{array}{l}\text { God has not } \\
\text { agreed }\end{array}$ \\
\hline $\begin{array}{l}\mid \text { sì-’'-kà?-lí| } \\
\text { God-TM -Neg.-sleep }\end{array}$ & [sǐkàYlí] & Sikali & $\begin{array}{l}\text { God has not } \\
\text { agreed }\end{array}$ \\
\hline $\begin{array}{l}\mid \text { ykài- } \quad \text {-kài-pín| } \\
\text { Life-TM- Neg.-agree }\end{array}$ & [nkà?kàPpín] & Nkakaping & Life did not agree \\
\hline 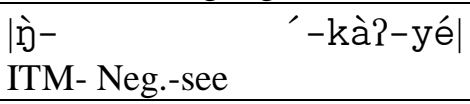 & [y̌kà?yé ] & Nkayé & I have not seen \\
\hline $\begin{array}{l}\left|\grave{n}-{ }^{\prime}-k a ̀ 2-3 j \hat{\varepsilon}\right| \\
\text { ITM-Neg.-know }\end{array}$ & [y̌kà?zjé ] & Nkaje & I don't know \\
\hline
\end{tabular}

From the table above, we observe that, the name [sǐkà?pín] is morphologically made up of: |sí-|"God", which is a noun that functions as subject, |kà?|is the Negation Marker, |pín|"accept, acknowledge" is the verb, yielding thus a negative verb phrase structure.

\subsubsection{Imperative Verb Phrase Names}

These are names that express order, command, either to the society or to the baby itself. Let us consider the examples:

Table 11

\begin{tabular}{|c|c|c|c|}
\hline Morphological Form & Phonetic Form & French writing & Glosses \\
\hline 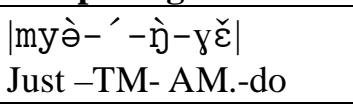 & 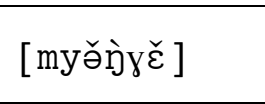 & Migue & Do it simply \\
\hline $\begin{array}{l}\text { |myə̀-' -’̀-y̌̌m| } \\
\text { Just -TM-AM.- hold }\end{array}$ & [myə̌ǹyǐm ] & Miguim & Hold it simply \\
\hline $\begin{array}{l}\mid \text { pín-' -pín| } \\
\text { accept -TM -accept }\end{array}$ & [pínpín] & Pingping & Just accept it \\
\hline $\begin{array}{l}\left|l \hat{i}-^{\prime}-1 \hat{i}\right| \\
\text { Search-TM -search }\end{array}$ & [lìlì] & Lili & $\begin{array}{l}\text { Continue } \\
\text { searching }\end{array}$ \\
\hline
\end{tabular}

From the table above, we observe that, the name [myə̌̀̀y $\check{\varepsilon}$ ] is morphologically made up of: |myə̀-|"just", which is an adverb that functions as an order marker, $|\grave{y}|$ is the Tense Marker, $|\gamma \check{\varepsilon}|$ "do" is the verb, yielding thus an imperative verb phrase structure.

\section{5- Sentence names}

Sentence names in Ghòmálá' is a concatenation of sentence elements, these include subject, verbs and object; this is structured as follows: sentence names $=\mathrm{S}+\mathrm{V}+\mathrm{O}$. Three types of sentences have been also identified: the affirmative sentence names, the interrogative sentence names, the negative sentence names and some If clause and conditional names.

\subsection{Declarative Sentence Names}


The declarative sentences express the acceptation of the social situation, the God fearing, or God believing mind of the father who gives or chooses such names for his child. Instances of declarative sentence names are given in the table below:

Table 12

\begin{tabular}{|c|c|c|c|}
\hline Morphological Form & Phonetic Form & French writing & Glosses \\
\hline $\begin{array}{l}\text { |mø̀-pín-yə́| } \\
\text { Cl1-person-agree-his }\end{array}$ & [mø̀pinyə́ ] & Mopinyé & $\begin{array}{l}\text { Everybody should } \\
\text { accept his own }\end{array}$ \\
\hline $\begin{array}{l}\mid \text { tèu-' -mbî-sí| } \\
\text { Strength-TM -to-God }\end{array}$ & [tòumbîsí] & Teubissi & $\begin{array}{l}\text { The strength is to } \\
\text { God }\end{array}$ \\
\hline
\end{tabular}

From the table above, we observe that, the name [mø̀pínyə́] is syntactically made up of : |mø̀-|"somebody, person" that function as subject, |'|the high tone here is the Tense Marker, |pín|"accept" is the verb and |-yó| is the possessive pronoun, functioning as object, yielding thus the $\mathrm{S}+\mathrm{V}+\mathrm{O}$ structure of the sentence. On the other hand, the name [tə̀umbîsí] is actually a declarative sentence meaning the strength belongs to God.

\section{5 .2 Interrogative Sentence Names}

These encompass rhetorical questions on the human condition in the daily evens. This is the structure: Noun+ Tense Marker (TM) +Verb+ Interrogative Pronoun. Let us consider the examples:

Table 13

\begin{tabular}{|c|c|c|c|}
\hline Morphological Form & Phonetic Form & French writing & Glosses \\
\hline $\begin{array}{l}\text { |nwə̀-'-ták-ndyé-wó| } \\
\text { Issue-TM-miss-house who }\end{array}$ & [nwǒtákndyéwó ] & Nutakdiewo & Whose house hasn't got problems? \\
\hline $\begin{array}{l}\text { |sí-pǿ-wó| } \\
\text { God-with-who }\end{array}$ & [sípǿwó] & Sipowa & Who can challenge God? \\
\hline 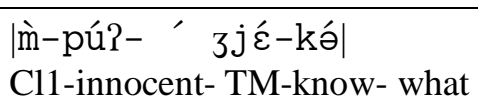 & [ m̀bú23j ćkó ] & Boujeke & What does an innocent man know? \\
\hline
\end{tabular}

From the table above, we observe that, the name [nwə̌ǹtákndyéwó] is syntactically made up of:|nwə-|"issue, problem" which function as subject, $\mid$ '|the high tone here is the Tense Marker, $|-\grave{y}-|$ is the Aspect Marker $\mid$ ták|"lack, miss" is the verb ,|ndyé| stands for house and $|-w o ́|$ is the interrogative pronoun, functioning as object, yielding thus the $\mathrm{S}+\mathrm{V}+\mathrm{O}$ structure of the sentence. On the other hand, the name [sípǿwó] is actually an interrogative sentence meaning who can challenge God?

5.3Negative sentence names

These are names that express negation as a whole sentence. They have the structure: SUBJECT + NEG + VERB+(OBJECT). Let us consider the examples:

Table 14

\begin{tabular}{|c|c|c|c|}
\hline Morphological Form & Phonetic Form & French writing & Glosses \\
\hline $\begin{array}{l}\text { |nwə̀-tí-ǹ-t jjě-sí-pó| } \\
\text { Issue-Neg.-Asp pass-God.-Neg. }\end{array}$ & 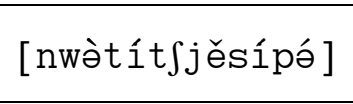 & Noutchetchiesi & $\begin{array}{l}\text { Nothing can } \\
\text { overwhem God }\end{array}$ \\
\hline $\begin{array}{l}\text { |kà?-kà?-pín| } \\
\text { life -Neg.-accept }\end{array}$ & [kà?kàPpín] & Kakaping & $\begin{array}{lll}\text { Life did not } \\
\text { accept }\end{array}$ \\
\hline $\begin{array}{l}\text { |'̀-kà?-kónnyə̀| } \\
\text { I -Neg.-deny }\end{array}$ & [ j̀kà?kónnyə̀] & Nkakengne & I haven't denied \\
\hline $\begin{array}{l}\mid \text { mbù-' -tì-myə̀| } \\
\text { grudge-TM- Neg.- finish }\end{array}$ & [mbǔtìmyə̀] & Boutimi & Endless grudge \\
\hline $\begin{array}{l}\text { |nwə̀-kíl-lè-t Jóm| } \\
\text { Issue- Asp-Neg. - care }\end{array}$ & [nwə̀kíPlغ̀tfóm ] & Nukiletchom & $\begin{array}{l}\text { Problems never } \\
\text { care where it } \\
\text { happen }\end{array}$ \\
\hline
\end{tabular}




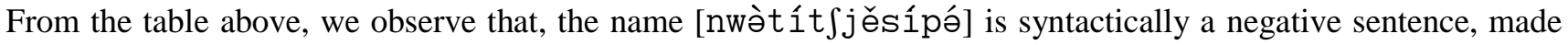
up of: |nwə̀-|"issue, problem" that function as subject, $|t \hat{1}|$ is the negation marker, $|-\grave{n}-|$ is the Aspect Marker | $t \int j e ̌ \mid$ "pass, overwhelm" is the verb, $|\mathrm{sí}|$ stands for God |, functioning as object, yielding thus the $\mathrm{S}+\mathrm{V}+\mathrm{O}$ structure of the sentence.

5.4 Some If clause and conditional $\mathrm{m}$ names

Table 15

\begin{tabular}{|c|c|c|c|}
\hline Morphological Form & Phonetic Form & French writing & Glosses \\
\hline $\begin{array}{l}\mid \text { pon-ǹ-pín| } \\
\text { well-coord -accept }\end{array}$ & [pònm̀bín] & Pongbing & $\begin{array}{l}\text { If you are well, } \\
\text { acknowledge it. }\end{array}$ \\
\hline $\begin{array}{l}\text { |mbǐ-sì-lòt̀ } \mid \\
\text { If - God - says }\end{array}$ & [mbǐsìlòt̀ ] & Bisileu & If God says it \\
\hline
\end{tabular}

\section{6- The semantic value of Ghòmálá’ names}

In this section we will discuss the meaning of names; in Ghòmálá' there are masculine names, feminine names, twins and circumstantial names. Many names that are given to children in this area have a meaning; the meanings vary according to the day that you were born on.

6.1 Masculine names

Masculine names are names that are given exclusively to male child. Some of these start with the prefix: |tá|"father", |fò-|"king"

Table 16

\begin{tabular}{|l|l|l|l|}
\hline Morphological Form & Phonetic Form & French writing & Glosses \\
\hline $\begin{array}{l}\text { |tá- mø̊ } \\
\text { father person }\end{array}$ & [támø̀ $]$ & Tamo & Somebody's father \\
\hline $\begin{array}{l}\text { ffò-zǿ } \mid \\
\text { King name }\end{array}$ & [fò-zǿ] & Fotso, Fozeu & The king of name \\
\hline
\end{tabular}

Such names can be put into feminine forms; in this case, we will have a double prefixation with |mé-|"mother".

Table 17

\begin{tabular}{|c|c|c|c|}
\hline Morphological Form & Phonetic Form & French writing & Glosses \\
\hline $\begin{array}{l}\mid \text { ḿ́-tá-mø̀ } \mid \\
\text { Mother-father- person }\end{array}$ & [métámø̀] & Matamo & $\begin{array}{l}\text { The mother of } \\
\text { somebody's father }\end{array}$ \\
\hline $\begin{array}{l}\mid \text { mé-fò-zǿ } \mid \\
\text { Mother- King - name }\end{array}$ & [méfòzǿ] & Mafotso & $\begin{array}{l}\text { The mother of the } \\
\text { king of name }\end{array}$ \\
\hline
\end{tabular}

\section{2 Feminine names}

Feminine names are names that are given exclusively to female child. Some of these start with the prefix: $\mid \mathrm{m} \varepsilon-$ |"mother", |ǹzwí-|"wife".

Table 18

\begin{tabular}{|c|c|c|c|}
\hline Morphological Form & Phonetic Form & French writing & Glosses \\
\hline $\begin{array}{l}|\grave{n}-3 w 1 ́-\grave{n} 3 \hat{\varepsilon}| \\
\text { Cl1wife prohibition }\end{array}$ & [ǹzwíǹzé ] & Djuidje & $\begin{array}{l}\text { The wife of } \\
\text { pohibition }\end{array}$ \\
\hline $\begin{array}{l}\mid \text { ǹ-3wí-sî| } \\
\text { Cl1wife God }\end{array}$ & [ǹzwísǐ ] & Djuissi & The wife of God \\
\hline $\begin{array}{l}\mid \text { ǹ-zwí-kòm| } \\
\text { Cl1wife group }\end{array}$ & [ǹzwíkòm ] & Djuikom & $\begin{array}{l}\text { The wife of the } \\
\text { group }\end{array}$ \\
\hline $\begin{array}{l}|\mathrm{m} \dot{\varepsilon}-\mathrm{k} \dot{\varepsilon} \mathrm{m}-\mathrm{t} e \check{ }| \\
\text { Mother notable trade }\end{array}$ & [mékśmtě] & Makamté & $\begin{array}{l}\text { The mother of the } \\
\text { notable of }\end{array}$ \\
\hline
\end{tabular}


commerce

For the masculinisation of feminine names, there are two rules that apply; for the names bearing the prefix |ǹzwí-|"wife", there is double prefixation with |tá-|"father" coming first. Whereas the names bearing the prefix |ḿ-|"mother", there will be a commutation or substitution of |mé-|"mother" by |tá-|"father".

Table 19

\begin{tabular}{|c|c|c|c|}
\hline Morphological Form & Phonetic Form & French writing & Glosses \\
\hline 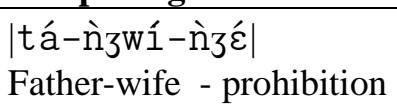 & [táǹzwíǹzé ] & Tadjuidje & $\begin{array}{l}\text { The father of the } \\
\text { wife of pohibition }\end{array}$ \\
\hline $\begin{array}{l}\mid \text { tá-ǹzwí-š̌ } \mid \\
\text { Father - wife -God }\end{array}$ & [táǹzwísǐ] & Tadjuissi & $\begin{array}{l}\text { The father of the } \\
\text { wife of God }\end{array}$ \\
\hline $\begin{array}{l}\mid \text { tá-ǹzwí-kòm| } \\
\text { Father - wife group }\end{array}$ & [táǹzwíkòm] & Tadjuikom & $\begin{array}{l}\text { The father of the } \\
\text { wife of the group }\end{array}$ \\
\hline $\begin{array}{l}\mid \text { tá-kém-tě| } \\
\text { father -notable - trade }\end{array}$ & [tákémtě] & Takamté & $\begin{array}{l}\text { father of the of the } \\
\text { notable of } \\
\text { commerce }\end{array}$ \\
\hline
\end{tabular}

From this table, we observe that Ghòmálá' speakers give names to their children according to the day they were put to birth. If a child was born on the «prohibitions day », then he is given a specific name like Djuidje "wife of the prohibition" Tadjuidje "father of the wife of the prohibition" the prohibition day according to the calendar of that area, which is made up of 08 days, is like Sunday in the Christian tradition. That is supposed to be the day that God rested after the creation of the universe.

6.3 Twins or neutral Names

From your name they know if you are a twin; such names bear the Suffix: |-mǿnyə|"twin". These names cannot be inherited, unless the child was borne haphazardly in the same circumstances with the person whose name is being given to the baby child. Circumstantial names can be given both to male and female baby child.

Table 20

\begin{tabular}{|c|c|c|c|}
\hline Morphological Form & Phonetic Form & French writing & Glosses \\
\hline 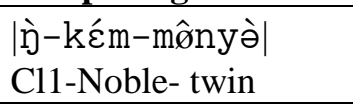 & [ǹkémmø̂nyə̀ ] & Kammogne & Twin's name \\
\hline 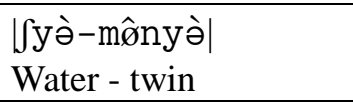 & [ Jyə̀mø̂nyə̀ ] & Chemogne & Twin's name \\
\hline $\begin{array}{l}\mid \text { pwò?-mônyə̀| } \\
\text { Sacrifice - twin }\end{array}$ & [pwò?mø̂nyə̀ ] & Pouomogne & Twin's name \\
\hline $\begin{array}{l}\text { |kə̀n-mø̂nyə̀| } \\
\text { Pipe twin }\end{array}$ & [kə̀nmø̂nyə̀ ] & Kenmogne & $\begin{array}{l}\text { The pipe of the } \\
\text { twin }\end{array}$ \\
\hline
\end{tabular}

Here in the table, the 1st syllable stands for first syllable of the name of the paramount king of the village or kingdom where the twins are borne. This is given to the second twin who came second; whereas the first is given the name $\mid \mathrm{k} \varepsilon$ m-mônyəे|" the noble of the twin". Some names are Circumstantial if a child is born straight after twins were born in a family he receives automatically the name [kónmø̂nyə̀], which means that you are the pipe (smoking) of the twins. In any Ghòmálá' name, the suffix $\mid$-mônyə̀| is related to twins.

6.4 Circumstantial or neutral names

Some circumstantial names include orphans and prince/princess names.

Table 21

\begin{tabular}{|l|l|l|l|}
\hline Morphological Form & Phonetic Form & French writing & Glosses \\
\hline $\begin{array}{c}\text { ntú?- - } \mathrm{k} \hat{\varepsilon} \mathrm{m} \mid \\
\text { Cup AM noble }\end{array}$ & Toukam & $\begin{array}{l}\text { The cup of the } \\
\text { noble }\end{array}$ \\
\hline
\end{tabular}




\begin{tabular}{|c|c|c|c|}
\hline $\begin{array}{l}\mid \text { tì-mô-mbè| } \\
\text { Neg -person - compound }\end{array}$ & [ tìmômbè] & Timobé & $\begin{array}{l}\text { Nobody was in the } \\
\text { compound }\end{array}$ \\
\hline $\begin{array}{l}\mid \text { tì-3y̌̌-tá| } \\
\text { Neg-know- father }\end{array}$ & [tìzyčtá] & Tijeta & $\begin{array}{l}\text { He who does not } \\
\text { know his father }\end{array}$ \\
\hline
\end{tabular}

If you are the first born of the Paramount Chief (Fo) you will be given the name: Toukam "the cup of nobleness"

- Some names are Onomatopoeias;

Table 22

\begin{tabular}{|l|l|l|l|}
\hline MorphologicalForm & PhoneticForm & French writing & Glosses \\
\hline $\begin{array}{l}\text { t } t \text { úm- } t \int w a ̀ ? \mid \\
\text { Drop - onomatopoeia }\end{array}$ & [t fúmt $\left.\int w a ̀ ?\right]$ & Tchumtchwa & To drop, to land \\
\hline
\end{tabular}

This name is given to whoever gets out of the womb with the feet.

\section{Discussion of the Results}

Naming practice in the Ghòmálá' area reinforces kinship, parentage and relationship ties. In Ghòmálá', not all the names are inheritable, because there are circumstantial names that rely on the conditions, manners and circumstances in which the child was born. From the morpho-syntatic analysis, we can see how the Ghòmálá ' people believe in God the almighty, that is unique and universal. God is at center of their live condition.

From the name bearing the morpheme|sì-|at the name initial, median or final position, we see the close relationship these people have with God. They do believe in him as the one who can accept or refuse anything. The Ghòmálá' native speakers believe in the mystical power of twins, this is why twins are given special names related to nobleness or to the king's name. Since twins are so special, they are given special names that cannot be inherited, those that have given birth to twin babies will receive the title of $\mid \mathrm{m} \varepsilon$-nyə̀|"mother of twins" or |tányə̀|"father of twins"

\section{Conclusion}

This article set out to find answers to the following queries: to which extent can naming contribute to cultural nationalism in Cameroon? What is behind the sounds that make up the morphemes and the words used in Ghòmálá' language as Names? What are the morpho-syntactic structure and the semantic implications of names in this area? What are the criteria for naming one's child in this area? We can conclude from the above analysis that naming in the Ghòmálá' linguistic area, portrays the thought and the believes of the people, from the internal structure of names, we see that they do believe in God almighty, who is the Alpha and Omega of everything that can happen in their social milieu. Each Ghòmálá' child should therefore endeavour to learn about the meaning of the name he is bearing. Twins have special names because they are so special, because even the modern obstetrician can hardly explain. And that is why mothers and fathers of twins are also given special and respectful nicknames that are so close the nobleness. At the dusk of this article, one can wonder what might be the sociolinguistic significance of the naming in the Ghòmálá area. But that is another research topic that deserves to be looked into next time.

\section{References}

Dieu, Michel Et Renaud, Patrick. 1983. Atlas linguistique du Cameroun. Yaoundé. DGRST.

Domche, Jeannot, Lambert Tagne, and Joseph Kamga. 2008. Və bín gké. Lire et écrire le ghomálá', Vol.1. Manuscript.

Domche, Jeannot, Gabriel Mba, and Edmond Nokam. 2008. Və bín gké. Lire et écrire le ghomálá’, Vol.2. Manuscript.

Domche, Jeannot, Gabriel Mba, and Edmond Nokam. 2009. Və bín gké. Lire et écrire le ghomálá’, Vol.3. Manuscript.

Duranti, Alessandro.2001. LinguisticAnthropology: A Reader. Malden, MA: Blackwell. 
Duranti, Alessandro. 2003. Language as Culture in U.S. Anthropology: Three Paradigms.

Current Anthropology 44(3):323-348.

Duranti, Alessandro. 2004. Companion to Linguistic Anthropology. ed, Malden, MA: Blackwell

Ekanjume-Ilongo, Beatrice. 2014. The Naming Practice in Akoose: Deviation from Cultural

Stereotypes. International Journal of English Language \& Translation Studies. 2 (2), 228-235

Grimes, Barbara. 2010. Ethnologue: Languages of the world. Vol 1, 14 ed, SIL, DALLAS, Texas

Harris, Zellig. 1957. Structural linguistics. Chicago, London; Phoenix Books. The University of Chicago. 383p.

Lévi-Strauss, Claude.1958a.«L'analyse structurale en linguistique et en anthropologie».Anthropologie structurale, Paris, Plon, pp. 37-62.

Lévi-Strauss, Claude. 1958b. «Linguistique et anthropologie». Anthropologie structurale. Paris, Plon, pp. 7791.

Lévi-Strauss, Claude. 1973. Anthropologie structurale. Paris, Plon.492P

Bloomfield, Leonard.1933.Language. New York, Hoh, Rinehart and Winston.566p.

Tamanji PN, Ndamsah GL. 2004. Constituent structure of the Associative construction in Grassfield Bantu. Journal of West AfricanLanguages31(1): 65-88.

Nzali, Jean-Pierre.1987. J'ai perdu mon nom. Yaoundé; SOPECAM. 105p 